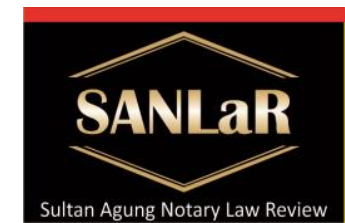

Volume 3 No. 1, March 2021
Sultan Aqung

Notary Law Review
ISSN 2686-4428

published by

Master of Notarial Law

Universitas Islam Sultan Agun Semarang

Implementation of Notary Responsibility...( Cindy Zakiyyatul Miskiyya)

\title{
Implementation of Notary Responsibility for Loss of Assets Due to Notary Error
}

\section{Cindy Zakiyyatul Miskiyya *) Gunarto ${ }^{* *}$ and Umar Ma'ruf ${ }^{* * *}$ )}

*) Student of Master of Notary Law, Faculty of Law, Universitas Islam Sultan Agung (UNISSULA) Semarang, E-mail: cindyzakiyya02@gmail.com

$\left.{ }^{* *}\right)$ Lecturer of Master of Notary Law, Faculty of Law, Universitas Islam Sultan Agung (UNISSULA) Semarang

${ }^{* * *}$ Lecturer of Master of Notary Law, Faculty of Law, Universitas Islam Sultan Agung (UNISSULA) Semarang

\begin{abstract}
The objectives of this research are 1) To find out and explain the implementation of the notary's responsibility for the loss of a certificate due to a notary's mistake. 2) To find out and explain the obstacles and solutions to the implementation of the notary's responsibility for the loss of a certificate due to a notary's mistake. The method used by researchers is Juridical Empirical (sociolegal research)and the specification in this research is including analytical descriptive. The sources and types of data in this study are primary data. And secondary data obtained from literature studies relating to the theory of criminal liability and legal certainty. Based on the results of that researchThe implementation of the notary's responsibility for the loss of the minuta deed due to a notary's mistake, namely making an official report which then reports it to the Regional Supervisory Council or the Regional Supervisory Council which will be followed up with efforts to resolve it. Meanwhile, sanctions for a Notary whose minimum certificate is lost due to a notary's mistake may be subject to written warning sanctions, honorific temporary dismissal and dishonorable discharge. Of course, the imposition of this sanction will be carried out by the Regional Supervisory Council in accordance with the gravity or lightness of the violation committed by the notary concerned. The obstacle is making a report to the police with the contents of the report that the notary concerned has lost all important documents and files.
\end{abstract}

Keywords: Responsibility; Notary; Minuta Deed.

\section{Introduction}

The existence of high legal awareness in the community is one of the factors that encourages the public to make an agreement before a notary. High legal awareness in the community, which is marked by the increasing demand for notary services, the increasing standard of living of the community, the rapid advancement of technology and the increasing number of business fields available in various fields, giving rise to and encouraging business people to increase their business activities in various fields. 
Therefore it is very necessary to have a Notary deed in the practice of legal traffic in an increasingly advanced and complex society. ${ }^{1}$

Notary is a position of trust. ${ }^{2}$ This implies that those who carry out their duties can be trusted and because the position of notary is a position of trust and people who carry out their duties and can also be trusted, both of which support each other. Therefore, in carrying out his / her duties, the Notary is obliged to keep and keep everything about the deed made and all information obtained in order to make the deed in accordance with the oath and promise of office.

The notary's position as a public official who is only authorized to make authentic deeds (unless otherwise stipulated by law) is also increasingly important. This is in accordance with Article 1 of Law of the Republic of Indonesia Number 2 of 2014 concerning Amendments to Act No. 30 of 2004 concerning the Position of Notary Public, which states that "Notaries are public officials who have the authority to make authentic deeds and other powers as referred to in the Law This law or based on other laws."

Notary office ethics concerns issues related to the attitude of Notaries based on values and morals towards Notary colleagues, society, and the State. With a service that is based on respect for human dignity in general and the dignity of a notary in particular, the characteristics of the notary profession are: ${ }^{3}$

1. Honest, independent, impartial, and responsible;

2. Prioritizing service to the interests of society and the state;

3. Does not refer to strings attached;

4. Rationality which means referring to objective truth;

5. Functional specificity, namely experts in the field of notary;

6. Solidarity between peers with the aim of maintaining the quality and dignity of the profession.

Notary as a confidant, is obliged to keep secret everything that is told to him in his position. The position of Notary as a position of trust automatically creates an obligation, where the obligation will end if there is an obligation according to law to speak, namely when someone is summoned as a witness. Legal protection is not only provided by the State to all Indonesian people, but also by a Notary for interested parties. ${ }^{4}$

Negligence or carelessness is one form of error. The error referred to in the Civil Code contains the meaning of an intentional act, to an unintentional act. The fundamental difference from deliberate neglect is that there is an intention from the heart of the doer. If the act which is done on purpose has been able to know with certainty about

\footnotetext{
${ }^{1}$ G.H.S. Lumban Tobing,1983.Peraturan Jabatan Notaris, Erlangga, Jakarta,Hal.2

${ }^{2}$ I Ketut Tjukup, 2016, "Notary Deed (Authentic Deed) As Evidence In Civil Legal Events". Acta Comitas (2016) 2 ISSN: 2502-8960 I e-ISSN: 2502-7573, p. 187.

${ }^{3}$ Herlien Budiono, 2008, A collection of writings on Civil Law in the field of Notary, Citra Aditya Bakti, Bandung, p. 25

${ }^{4}$ M. Adam, 1985, Notary and Legal Aid, Sinar Baru, Bandung, p. 13
} 
the consequences or consequences that will arise, while the act of negligence by the offender does not intend to cause harm in his heart, the perpetrator may even have the desire to prevent the loss but not all of them are successful, because there is a part of obligations that were not carried out.

And one concrete example that occurred in the Notary Office of Demak Regency, there was a Notary in terms of ordering one of his staff employees to photocopy Minuta at the photocopying shop, because the machine in the office was broken. After the staff returned to the office, not realizing that the real Minuta had been left behind in the shop. By the time he returned to the shop, Minuta was gone and the shop employees did not know that Minuta was left behind in the photocopy shop. Notaries who disclose such secrets can be subject to article 322 of the Criminal Code, which is tantamount to exposing State secrets, even though Notaries have the obligation to keep them (Article 16 letter b UUJN).

Based on the problems above, the objectives of this study are as follows:

1. This is to find out and explain the implementation of the notary's responsibility for the loss of the deed due to the notary's mistake

2. This is to find out and explain the obstacles and solutions to the implementation of the notary's responsibility for the loss of the minimum deed due to the notary's mistake

\section{Research methods}

The research approach that researchers use is juridical empirical (sociolegal research). The Juridical Approach is used to analyze various laws and regulations related to the above problems, while the Empirical Approach is used to analyze the law by looking at a legal reality in society. ${ }^{5}$ This research is descriptive in nature, namely research that aims to describe the state of something in a certain area and at a certain time. The sources and types of data in this study are primary data. And secondary data obtained from literature studies relating to the theory of criminal liability and legal certainty.

\section{Result and Discussion}

\subsection{Implementation of Notary Liability for the Loss of Minuta Deed due to Notary's Error}

Notaries have the position of public officials who have the authority to make authentic deeds and other powers regulated in Act No. 30 of 2004 concerning Notary Positions. The notary provides legal certainty for the parties from the deed he makes. The function which is also the authority of the notary public as a public official is to make authentic deeds regarding all actions, agreements, and regulations required by laws and regulations and / or which the interested party wants to be stated in an authentic deed, guarantees the certainty of the deed creation date, keeps deeds, giving grosse,

\footnotetext{
${ }^{5}$ Zainudin Ali, 2009, Legal Research Methods, Sinar Grafika, Jakarta, p. 105
} 
copies and excerpts of deeds, all of that as long as the making of the deeds is not also assigned or excluded to other officials or other people stipulated by law. ${ }^{6}$

The conclusion of the civil liability for a Notary who commits an act against the law, the Notary is obliged to be accountable for his actions by being subject to civil sanctions in the form of compensation for expenses or compensation to the injured party for an illegal act committed by the Notary. However, before the Notary is subject to civil sanctions, the Notary must first be able to prove that there has been a loss resulting from an illegal act against the Notary against the parties, and between the loss suffered and the illegal act of the Notary, there is a causal relationship and the act against the law or carelessness is caused by an error that can be accounted for to the Notary concerned.

According to Notary Teguh Nugroho, SH, talking about responsibility means talking about sanctions. If a Notary is really proven to have committed an illegal act, the Notary will get sanctions. Types of Sanctions such as Civil, Administrative and Criminal Sanctions. $^{7}$

The implementation of the notary's responsibility for the loss of the minuta deed due to a notary's mistake in Demak Regency is to make an official report which then reports it to the Regional Supervisory Council or the Regional Supervisory Council which will be followed up by trying to solve it. Meanwhile, sanctions for a Notary whose minimum certificate is lost due to a notary's mistake may be subject to written warning sanctions, honorific temporary dismissal and dishonorable discharge. Of course, the imposition of this sanction will be carried out by the Regional Supervisory Council in accordance with the gravity or lightness of the violation committed by the notary concerned.

If it is related to the theory of legal responsibility that the author uses in the research method of writing this thesis, Hans Kelsen states that a person is legally responsible for a certain act. The form of responsibility that must be borne by a notary who commits a violation is individual responsibility, that is, a notary is responsible for the violation he has committed himself. So, according to the theory of legal liability, the notary is obliged to be responsible for the loss of the lost deed due to his own negligence or due to force majeure. If due to negligence, the notary must be subject to sanctions as a form of responsibility,

\footnotetext{
${ }^{6}$ Umar Ma'ruf, Dony Wijaya, Legal Review of the Position and Function of Notaries as Public Officials in Making Authentic Deeds (Case Study in Bergas District, Semarang Regency) Journal of Legal Reform Volume II No.3 September - December 2015

${ }^{7}$ Results of interviews with Teguh Nugroho, SH, M.Kn, as Notary in Demak Regency, October 15, 2020, at 13.30 WIB
} 


\subsection{Obstacles and Solutions to Implementing Notary Responsibilities for the Loss of Minuta Deeds Due to Notary Errors in Demak Regency}

The position of notary is an institution created by the state. ${ }^{8}$ Placing a notary as a position and profession that is deliberately made by laws and regulations for certain purposes and functions (certain authorities) and is sustainable as a permanent work environment. ${ }^{9}$

The position of a notary is held or its presence is desired by legal regulations with the intention of serving people who need authentic written evidence regarding circumstances, events, or legal actions. On this basis, those who are appointed as notaries must have the enthusiasm to serve the community, and for this service, people who have felt served by a notary in accordance with their job duties can provide honoraria to the notary, therefore a notary does not mean anything if the community does not need it. ${ }^{10}$

To find out the extent of the notary's responsibility as a public official, it can be studied from the theory of state power. With the theory of state power, it can be seen that the notary's position as a general official in the state power structure. One form of state service to the state to its people is that the state provides the opportunity for its people to obtain evidence or legal documents related to civil law. For this purpose, authority is given to public officials who are held by notaries. And the Minuta deed becomes a state archive which must be kept and guarded by a notary public for an indefinite time limit. ${ }^{11}$

Minuta is the original notary deed which must be kept by a notary public. The obligation to keep the minimum deed as part of the notary protocol is intended to maintain the authenticity of a deed by keeping the deed in its original form, so that if there is falsification or abuse of grosse, the copy or quotation can be found easily by matching it with the original. The notary protocol is a state archive that must be kept and maintained by a notary public. The protocol does not belong to the notary who makes the deeds and also does not belong to the notary who is assigned by the Minister of Law and Human Rights to keep it.

Through the deed he makes, the Notary must be able to provide legal certainty to the public who uses Notary services. ${ }^{12}$ A Notary Deed is an authentic deed that has legal force with a guarantee of legal certainty as a perfect written evidence (volledig bewijs), does not require additional other evidentiary tools, and the judge is bound by it.

\footnotetext{
${ }^{8}$ Bagir Manan, 2004, Indonesian Positive Law, UII Press, Yogyakarta, p .. 15

${ }^{9}$ Anonymus, Legal Arrangements Regarding the Existence of Missing or Damaged Notary Deeds due to Natural Disasters, Faculty of Law, University of North Sumatra.

${ }^{10}$ Habib Adjie, 2008, Civil and Administrative Sanctions against Notaries as public officials, Refika Aditama, Bandung, p. 27

${ }^{11}$ Tuti Irawati, 2010, Analysis of the responsibilities of a notary as a general official on deeds made and indicated as criminal offenses, Faculty of Law, University of Indonesia, Jakarta, p. 27.

${ }^{12}$ H. Salim HS. and H. Abdullah, 2007, Contract Design and MOU, Sinar Grafika, Jakarta, p. 101102
} 
Notary, apart from being authorized to make authentic deeds both by him and in front of him, which is his main daily task, the notary can also take the following actions

1. Acting as a legal advisor, especially concerning civil law issues in a broad sense (privaat);

2. Registering (waarmerking) on deeds or under-handed documents and documents (stukken).

3. Legalize signatures;

4. Creating and ratifying (waarmerking) copies or derivatives of various documents (copy collationee)

5. Endeavor to legalize such bodies

6. Limited Liability Companies / Foundations to obtain approval / ratification as a legal entity and the Minister of Justice and Human Rights. ${ }^{13}$

Sanctions are a means of coercion, in addition to punishment, they are also to obey the provisions stipulated in regulations or agreements. ${ }^{14}$ Sanctions are also defined as a means of coercion as punishment for not obeying the agreement. ${ }^{15}$ Sanctions are tools of power that are public law used by the authorities as a reaction to noncompliance with Administrative Law norms. Thus the elements of sanctions $v^{1}{ }^{16}$ as a tool of power, of a public legal nature, used by authorities and as a reaction to disobedience.

The obstacle in carrying out the notary's responsibility for the loss of the minimum certificate due to a notary's mistake in Demak Regency is making a report to the police with the contents of the report that the notary concerned has lost all documents and other important files.

Minuta notary deed which contains signatures, witnesses, witnesses and notaries or other files lost (can be lost in one's own office or lost in another place or forgot to keep it or have not been bundled for a long time so that it is lost) or the minuta was burned or eaten by termites or was flooded or is no longer in the notary office anymore. If everything described above occurs, what the notary must do is to make a report of loss from the authorities (the police) or make another report, if not lost, such as being burned or eaten by termites or affected by a flood. All reports will be attached to the relevant minuta bundle. With the provision that the deed is recorded in the repertorium and in the claper. ${ }^{17}$

\footnotetext{
${ }^{13}$ Sentiya Dwi Ningsih, Munsharif Abdul Chalim, The Role of Notary in Making Financing Deeds in Islamic Banks According to Act No. 2 of 2014 concerning Notary Position, Journal of Deeds Vol. 4. No. 1, March 2017: 79-82

14 N. Elgra, 1983, HRWgokkel et al, Dictionary of Legal Terms Fockema Andrea, Dutch-Indonesian, Binacipta, Jakarta, p. 29

${ }^{15}$ S. Wojowasito, 1995, Dutch-Indonesian General Dictionary Ichtiar Baru-VanHoeve, jakarta, p.560

${ }^{16}$ Philipus M.Hadjon, 2002, Introduction to Indonesian Administrative Law, Gajah Mada University Press, Yogyakarta, p. 245

17 http://www.notary.my.id/2017/01/minuta-notaris-hilang-atau-rusak.html, accessed on December 1, 2020 at 21.56 WIB
} 
Notary Public Teguh Nugroho, states that if there is a lost deed, the notary is obliged to make an official report regarding the loss that occurred in the certificate and report the minutes to the Supervisory Council The contents of the minutes include how the minuta deed is lost, what causes the loss of the certificate, and evidence is attached. Furthermore, from the report submitted to the Supervisory Board, the notary can ask for suggestions and solutions from the Supervisory Council regarding how to resolve the problem. ${ }^{18}$

The solution to overcome the obstacles in the implementation of the notary's responsibility for the loss of the deed's minimum due to a notary's mistake in Demak Regency concludes that the settlement that can be done by the notary in the event of a loss of the deed's minuta is to first prepare an official report regarding the loss of the minimum deed which states how the condition of the loss of the minimum deed whether only minor loss or eliminating the essence of the deed and attaching evidence of the loss then reported to the Supervisory Board.

According to the author, the obstacles and solutions to the implementation of the notary's responsibility for the loss of a certificate due to a notary's mistake in Demak Regency are viewed using the theory of legal certainty, basically, preventive legal protection and repressive legal protection. Preventive legal protection includes actions that lead to efforts to prevent disputes, while repressive protection means protection that is directed more towards resolving disputes such as dispute settlement in court.

\section{Closing}

\subsection{Conclusion}

1. The implementation of the notary's responsibility for the loss of the minuta deed due to a notary's mistake in Demak Regency is to make an official report which then reports it to the Regional Supervisory Council or the Regional Supervisory Council which will be followed up by trying to solve it. Meanwhile, sanctions for a Notary whose minimum certificate is lost due to a notary's mistake may be subject to written warning sanctions, honorific temporary dismissal and dishonorable discharge. Of course, the imposition of this sanction will be carried out by the Regional Supervisory Council in accordance with the gravity or lightness of the violation committed by the notary concerned.

2. The obstacle in carrying out the notary's responsibility for the loss of the minimum certificate due to a notary's mistake in Demak Regency is making a report to the police with the contents of the report that the notary concerned has lost all documents and other important files. The solution to overcome the obstacles in the implementation of the notary's responsibility for the loss of the deed's minimum due to a notary's mistake in Demak Regency concludes that the settlement that can be done by the notary in the event of a loss of the deed's minuta is to first prepare an official report regarding the loss of the minimum deed which states how the condition of the loss of the minimum

\footnotetext{
${ }^{18}$ Results of interviews with Teguh Nugroho, SH, M.Kn, as Notary in Demak Regency, October 15, 2020, at 13.30 WIB
} 
deed whether only minor loss or eliminating the essence of the deed and attaching evidence of the loss then reported to the Supervisory Board.

\subsection{Suggestion}

1. In terms of saving Minuta, the notary should be more careful in maintaining, storing and placing it.

2. Notaries can save Minuta in electronic form as a back up of original Minuta, and can be used as evidence if the Minuta is lost and comply with applicable legal provisions and are based on morals and ethics.

\section{References}

Journals:

[1] I Ketut Tjukup, 2016, "Notary Deed (Authentic Deed) As Evidence In Civil Legal Events". Acta Comitas (2016) 2 ISSN: 2502-8960 I e-ISSN: 2502-7573

[2] Sentiya Dwi Ningsih, Munsharif Abdul Chalim, Peran Notaris Dalam Pelaksanaan Pembuatan Akta Akad Pembiayaan Di Bank Syariah Menurut Undang-Undang Nomor 2 Tahun 2014 Tentang Jabatan Notaris, Jurnal Akta Vol. 4. No. 1, Maret 2017: 79-82

[3] Tuti Irawati, 2010, Analisa Tanggung jawab notaris sebagai pejabat umum terhadap akta yang dibuat dan berindikasi perbuatan pidana, Fakultas Hukum Universitas Indonesia, Jakarta

[4] Umar Ma'ruf, Dony Wijaya, Tinjauan Hukum Kedudukan Dan Fungsi Notaris Sebagai Pejabat Umum Dalam Membuat Akta Otentik (Studi Kasus di Kecamatan Bergas Kabupaten Semarang) Jurnal Pembaharuan Hukum Volume II No.3 September - Desember 2015

Books:

[1] Bagir Manan. (2004). Indonesian Positive Law, UII Press, Yogyakarta

[2] GHS Lumban Tobing. (1983). Regulation of Notary Position, Erlangga, Jakarta

[3] H. Salim HS. and H. Abdullah. (2007). Contract Design and MOU, Sinar Grafika, Jakarta

[4] Habib Adjie. (2008). Civil and Administrative Sanctions against Notaries as public officials, Refika Aditama, Bandung

[5] Herlien Budiono. (2008). A collection of writings on Civil Law in the field of Notary, Citra Aditya Bakti, Bandung

[6] M. Adam. (1985). Notary and Legal Aid, Sinar Baru, Bandung

[7] N. Elgra. (1983). HRWgokkel et al, Dictionary of Legal Terms Fockema Andrea, Dutch-Indonesian, Binacipta, Jakarta 
[8] Philipus M.Hadjon. (2002). Introduction to Indonesian Administrative Law, Gajah Mada University Press, Yogyakarta

[9] S. Wojowasito. (1995). Dutch-Indonesian General Dictionary Ichtiar BaruVanHoeve, Jakarta,

[10] Zainudin Ali. (2009). Metode Penelitian Hukum, Sinar Grafika, Jakarta Internet:

http://www.notary.my.id/2017/01/minuta-notaris-hilang-atau-rusak.html, accessed on December 1, 2020 at 21.56 WIB 